\title{
BORIS E 0 CURSO LIVRE DE RUSSO
}

\section{Augusto de Campos}

\author{
Poeta, tradutor e crítico literário.
}

Eu fui aluno de Boris Schnaiderman entre 1962-1964. Formado em Direito, e não em Letras, eu era profissionalmente o que se chamava Advogado do Estado, e hoje é intitulado Procurador do Estado, carreira onde acabara de entrar por concurso público, tendo disputado 40 vagas com 1500 inscritos. Como eu não tinha ligação com a Faculdade de Filosofia e Letras, da USP, consegui, com uma carteirinha de ouvinte, frequentar o curso livre de russo ministrado por Boris na rua Maria Antônia. Queria, como Haroldo, traduzir Maiakóvski. Lê-lo no original, e não através das aguadas versões que por aqui circulavam, regurgitadas de traduções literais em castelhano, que o transformavam em orador de palanque. A primeira aula tinha uns 50 alunos. Para animar, Boris punha num toca-discos a canção popular "Kalinka Maiá". Entusiasmados, os alunos entoavam coletivamente as duas palavras enganosamente fáceis que se repetiam ao longo da singela melodia. Depois começaram as duras aulas de aprendizado do alfabeto cirílico, as lições de casa. As vexaminosas leituras públicas dos textos. O número de alunos foi diminuindo progressivamente. A certa altura, inscreveu-se no curso Aurora Bernardini, que já possuía um razoável conhecimento do idioma. Quando veio o golpe militar de 31 de março e/ou $1^{\circ}$ de abril de 1964, a sala ostentava em torno de meia-dúzia de alunos. Pouco depois, o curso se extinguiu. Como era natural, o ensino do russo era altamente suspeito aos olhos da ditadura.

Boris, com quem Haroldo e eu começáramos a traduzir os poetas modernos russos, indicou-nos uma livraria que ficava na rua Direita, no centro da cidade, onde compramos um grande número de livros, a preço de banana. Eram, de fato, muito baratos os livros russos, edições estatais. Lá adquiri, entre vários outros, os treze volumes das Obras Completas de Maiakóvski, publicados entre 1955 e 1960, encadernados em capa vermelho-escura, com letras douradas, recheados de ilustrações em cores de autoria do poeta, em tiragens de até 200.000 exemplares. Mais tarde, passei a indicação ao Leminski, que afetava conhecer o idioma, embora na verdade o que sabia era só um pouco de polonês... Comprei, também, à 
mesma época, os cinco volumes azulprateados de uma seleção de poemas de Sierguei Iessênin, 500.000 exemplares! O dono da livraria era um russo "branco", que se evadira da URSS e que obviamente não tinha nada de comunista. Chamava-se Sérgio Uspienski. Depois do golpe militar de 1964, a livraria não durou muito. Um belo dia, foi visitada pela polícia política, que pôs abaixo as suas estantes, e acabou com a nossa alegria.

Editadas após a reabilitação do "futurista" Maiakóvski por intervenção direta de Stalin, que se apercebera, ladinamente, da vantagem de ter uma voz tão extraordinária alardeada como "o poeta da revolução", as obras completas não podiam deixar de imprimir as suas composições do período mais radical do cubo-futurismo, com as quais se iniciava o primeiro tomo da coletânea. Salvo um ou outro corte da censura para alguma palavrinha tipo "merda", e algum trecho mais suspeito de insurreição (que ia para algum apêndice), a edição parece ser realmente completa. De um dos textos relegados aos apêndices extraí o meu profilograma "Chuva Oblíqua de Maiakóvski", que embuti em montagem no perfil maiakovskiano de Ródtchenko, impresso em vermelho, fazendo incidir sobre ele, à maneira de um caligrama apollineriano, as palavras do texto, que Ossip Brik censurara ao poeta russo, e no qual este dizia que queria ser compreendido pelo seu país, mas que, se não o fosse, passaria por ele como chuva... "Chuva oblíqua", intitulei, propositadamente, a minha "intradução", pensando em unir à estrofe marginal do "opus" não numerado maiakovskiano a voz de um outro grande poeta marginalizado em seu tempo, Fernando Pessoa, num de seus poemas mais radicais, da fase "interseccionista". Metapoesia marginal. Três poetas num só.

Os poemas do período mais caracteristicamente cubofuturista de Maiakóvski nos interessaram muito, a mim e Haroldo. Escancaravam a face oculta do poeta: o seu artesanato furioso, expresso nas imagens ofensivas, nos imprevistos jogos vocabulares e nas rimas esdrúxulas e desconcertantes que passavam despercebidas nas versões literais. Características que marcam toda a sua obra ulterior. Traduzimos vários deles, que vieram a ser incluídos nos volumes dos nossos Poemas de Maiakóvski e da nossa Antologia da Poesia Russa Moderna, obras essas publicadas em 1967 e 1968, pela editora Tempo Brasileiro e pela Editora Brasiliense, desafiando a censura militar, que mirava especialmente Enio da Silveira, diretor desta última. A seguir, a Editora Perspectiva veio a republicar as mesmas obras, ampliadas. Mais recentemente, numa das minhas periódicas revisitas à poética russa, criei coragem, retomei meus estudos e voltei a esse grupo de poemas que sempre me atraiu. Já sem contar com o apoio logístico de Boris, e com o amparo relativo de vários dicionários e de algumas traduções de outros idiomas mais amigáveis, animei-me ao adquirir a antologia bilíngue de Claude Frioux, Maïakovski, Vers 1912-1930 (Paris, L'Harmattan, 2001), que corresponde à sequência 
inicial de poemas do primeiro tomo da edição russa de sua obra poética completa. Como os franceses veem surrealismo em tudo, Frioux tende a considerar precocemente "surrealistas" os versos juvenis de Maiakóvski.

A mim eles me parecem mais influídos pelas matrizes do cubismo e do expressionismo, então correntes, sem falar no difuso futurismo citadino que impregna, entre o ruído dos pneus e o visual das tabuletas, as imagens violentas, disparatadas e simultaneístas desses poemas. As versões de Frioux são literais e apresentam, por isso mesmo, limitada criatividade poética, mas são, também por isso, de grande utilidade para a compreensão e interpretação dos textos, duplamente difíceis, pelo idioma e pela complexidade. Com o reforço de tais recursos verti mais doze poemas daquela fase, que se situa entre 1912 e 1915. Sem perceber, traduzi dois que já haviam sido vertidos, um por Haroldo, outro por mim. Publiquei sete deles na revista eletrônica Zunái, dirigida pelo poeta Cláudio Daniel (http://zunai.com.br/post/96283159708/torre-de-babel1). Diferentemente de alguns tradutores, que se sentem irresistivelmente atraídos a desafiar as recriações de outros, para competir com eles - como se apreciassem o papel daqueles jovens "cowboys" que vão procurar o velho pistoleiro aposentado para chamá-lo ao confronto nos conhecidos "western" cinematográficos - tenho por princípio evitar essas coincidências embaraçosas e quase sempre humilhantes para os "sparrings". Para que traduzir aquilo que já foi transcriado tão bem e provavelmente melhor? Mas aconteceu, e fica, ao menos, no caso do poema vertido pelo Haroldo, como um contraponto fraterno de "irmão siamesmo". Quanto a competir comigo mesmo, não tenho o que dizer. Não deixa de ser engraçado, porque as traduções se revelam completamente diferentes.

Augusto de Campos é poeta, tradutor, crítico literário e musical e ensaísta brasileiro. É considerado um dos principais representantes do concretismo brasileiro, movimento literário que teve seu início em 1956. Ao lado do irmão, Haroldo de Campos, e de Décio Pignatari, deu início ao grupo Noigandres, que seria importante para o movimento concretista. Foi aluno de Boris no curso livre de russo, da Faculdade de Filosofia da USP, ainda na Rua Maria Antônia, em São Paulo. 